\title{
The 'Typology of Sasaknese Muslim Scholars' Views in Lombok toward the Hybrid Contract as a Problem-Solving in Islamic Finance
}

\author{
Musawar \\ The State of Islamic University, Mataram -Indonesia \\ e-mail:musawwar_1@yahoo.com
}

\begin{abstract}
This paper studies the views of Sasaknese Muslim Scholars toward the Hybrid Contract, in Lombok. Island Indonesia in terms of their argumentations, typologies, and applications which becomes confusion in the society. The paper argues that problem in the transaction exists clearly. It is because of the limited meaning of Riba which is very strict that raises the society to fear to do the both in individual and group transactions since Riba have been probibited by Al-Qur'an. While, the globalization of economic world rapidly runs which people must catch up with it. Then, related to the financial aspect of the Islamic teaching is tasted that it is running at its place. Hence, it needs to the solution. One of the solutions is applying Hybrid Contract in the view of TGH where they are very influential the life of society. Moreover, Lombok island is popularly known as thousands mosque island and soon as being seen from different references and facts. Consequently, for understanding the above phenomenon, the researcher used qualitative approach, juridical approach, and sociology by collecting data through observation, and interview to know typology Muslim scholars about bybrid contract by a hope to be the contributions for the government to take a policy.
\end{abstract}

Keywords: Hybrid Contract, Sasaknese Muslim Scholar, Society Problem, and Muamalah. 


\section{INTRODUCTION}

The growth and development of the financial activities in Shari'ah institutions (LKS) in Indonesia today are very rapid as shown by the report of OJK where some institutions of Islamic finance as the Islamic banking, Islamic insurance, Islamic finance, and etc are gradually growing and developing. ${ }^{1}$ Hence, the practitioners, regulators, and even academics who have the attention in the field of Islamic financial actively and creatively response the growth of Islamic finance. This situation pushes the people who have an attention in Islamic law business to make their products free from usury (riba), gambling, deception and any crimes that are forbidden by al-Qur'an hadith (tradition) of the Prophet. Then, all the products were given a special identity addressing the Islamic value or are named by the Arabic name, like mudarabah (profit sharing), mushärakah (cooperation), rahn (mortgage) and etc. Even though all products have been known with a special identity, but it can be recognized as the valid contract by al-takyif al-figh (the review of fiqh) to know the validity in the aspect of the Islamic law.

As being known in the real life, the transaction done by people is one transaction, like in the form of buying and selling, pawning, tenancy, etc. But, the new facts show that the existence of two contracts which are combined into one as can be seen in the following examples: 1). The "shariab card" containing 3 (three) contracts, ijärah (rent), qard (loan), and kafälah (guaranty); ${ }^{2}$ ). The syari'ah bond ${ }^{3}$ has more or less than three contracts, 3).mudarabah (profit sharing) (orijärah) and wakälah (representation) and it is followed by kafälah or $\left.w a ' d^{4} 4\right)$. The product of "Gadai Syari'ab" has two contracts; rabn and ijarah, ${ }^{5}$ )

${ }^{1}$ See the related explanation with the growth of Islamic financial etc at http:// www.ojk.go.id/id/kanal/syariah/data-dan-statistik/statistik-perbankan-syariah/Pages/Statistik-Perbankan-Syariah---Februari -2016. aspx. Quoted at 27 February 2017.

2See the explanation about "shari'ah Card" in Harun, "Hybrid Contract Muamalah Dalam Aplikasi" at http://harun-mh, quoted at 27 Februari 2017

${ }^{3}$ Islamic bonds are a long-term securities issued by the principles of Shariah bond to holders of Shariah oblige the issuer to pay income to the holders of bonds of Shariah in the form of profit sharing/margin/fee and repay the bond at maturity. Futhermore see Fatwa "Dewan Syari'ah Nasional” Fatwa No: 32/DSN-MUI/IX/2002

4Abdul Hanan, Aspek. Hukum Dalam Penyelenggaraan Investasi di Pasar Modal Syariah Indonesia, (Jakarta: Prenanda Group, 2009), 118

${ }^{5} \mathrm{See}$ at Fatwa Dewan Syari'ah Nasional Nomor: 26/DSNMUI/III/2002Tentang Gadai Emas. 
The "Dana Talangan Haji" has two transactions; qard and ijaräb, ${ }^{6}$ 5). The "Bay" alMuräbahab" has two transactions; bay" andijärah. ${ }^{7}$ (). The "Mushärakah mutanäqișab" has two contracts; mushärakah and buying, ${ }^{8}$.7).The "Sandak contract" uses two transactions; rahn and isti'zan (tabarru')or bay." The examples above show that there are two contracts in each transaction that carried out simultaneously or at least every contract consists of two transactions that cannot be separated because all of those are a unity. The type of this transaction is known as the "Hybrid Contract" or "al-'uquid al- murakkabah " as in the contemporary contract (al-figh al-mu'amalat al-maliyah al-mu'așirab) which is one form of ijtibad of the Muslim scholars as an effort to escape from the shackles of usury that has prohibited by al-Qur'an and Sunnah, the source of Islamic law for Muslim life.

\section{THE ARGUMENTATION OF THE HYBRID CONTRACT}

As being known, some contracts have used the "Hybrid Contract" as the solution to the financial problem living in the middle of society, either in the modern transaction or classic. But, after checking to the books of the badith - as the second source of Islamic law, the explanation in badith has forbidden the compounding of two or three contracts in the contract, like the compounding of buying and tenancy as contract.It is shown by some traditions (badith), and one of these badiths is the voice of the honorable Prophet that reported by Imam al-Tirmiziy as the following text:

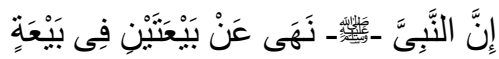

"Verily that the prophet forbids the combination of two contracts (such as buying) in a contract (purchasing)" 10

Literally, the meaning of that hadith is that the prophet forbids that transaction done by two contracts directly, such as the two buying (or selling)

'Muhamad Ahbar Ilyas, "Dana Talangan Haji Problem dan Relita Hukum di Kalangan Masyarakat" dalam http://blog.umy.ac.id/muhakbargowa/2012/09/26/ quoted 15 Februari 2017

${ }^{7}$ Asmuni Mth, Aflikasi Musyarakah Dalam Perbankan Islam, al-Mawardi, (Yogyakarta: Jurnal, edition 2004), 22

${ }^{8}$ The more explanation can be found at Fatwa Dewan Syari'ah Nasional No: 73/DSN-MUI/XI/2008, Tentang Musharakah Mutanaqisah.

'See at Musawar, Sandak Dalam Perspektif Tuan Guru (Studi Kasus di Lombok Nusa Tenggara Barat, (Yogyakarta: IAIN Sunan Kalijaga, Tesis, 2002)

10 See at Muḥammad bin Isa Abū 'Isā al-Turmuzi, al-Jāmíal-Șahiḥ Sunan alTurmuziy, (Baerut: Dār Iḥyā’ al-Turāth al-‘Arabiy, tt), volume III, 533 
contracts are combined in one buying contract. Moreover, it is supported by the hadith that is narrated by al-Baihaqiy in his book, where it also literally forbids a contract which is done by grouping two contracts directly. The prohibition is based on each contract functions that have different purposes. The supporting hadith is as following:

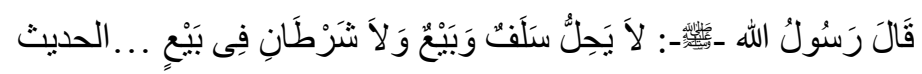

"The prophet said: "it is not allowed to do the loan and the buying (combined) and not allowed to have two requirements in a buying"11

Another similar in tone of hadith as the previous idea that the contract is not allowed to be done by two contracts as a group is the hadith that is narrated by Imam Ibnu Hambal. It explicitly forbids two contracts that are combined into one, as in the following text:

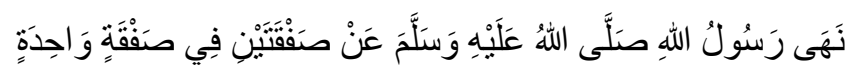

"The Prophet forbids the transaction such as the two (buying) in a purchasing"12

Strictly elaborating, according to some traditions (hadith) narrated by Muslim scholars above, that those traditions appear literally forbid that a contract cannot be established by two contracts. It means that a contract to which aims to fulfill the need of community or person must not in the form of combining two or more contracts in a contract. Based on the explanation related to some hadith explicitly forbid a contract containing two or more contracts, it is natural to ask whether financial products that use the Hybrid Contract can be deemed that the products have followed the principles of Shari'ah or not. It is because some hadith that are mentioned previously clearly forbid the use of the combination of contracts in a contract.

Therefore, this research is a very urgent matter with a complete and detail analysis from some products containing the Hybrid Contract from a Shari'ab financial institution or not Shari'ah institution too. Hence, this research describes what and how the actual concept of the Hybrid Contract and how the typology of Sasaknese scholars' views at Lombok Island against the Hybrid Contract in general is. The preliminary observation and interview show that some Sasaknese scholars' have different views on it. The different views as shown here are a phenomenon of development of Islamic law in Lombok

11 See further the more explanation in Sulaimān bin Aḥmad bin 'Ayūb Abū alQāsim al-Ṭabraniy, al-Mu'jam al-Kabìr, (Mushaf: Maktabah al-Ulūm wa al-Hukum, 1983), volume III, 107

${ }^{12} \mathrm{Ahmad}$ bin Hanbal Abu Abdillah al-Syaibaniy, Musnad al-Imam Ahmad bin Hambal, (al-Qahirah: Mu'assah Quthubah, without year), vol, I, 398 
island which is known as the "One Thousand Mosques Island", even though it is famous as the "World Halal Tourism" "and also "World's Best Halal Honeymoon Destination", ${ }^{14}$ it points that Lombok people are living infirm and settle religious value.

Surely, the mentioned phenomenon above is something which needs the attention of the academic world. Hence, it can be questioned, what the basic argumentation of Sasaknese Muslim scholars against the Hybrid Contract is, although the badith clearly forbids the use of two contracts in a contract. Then, why Sasaknese Muslim scholars in Lombok have the different outlook on the Hybrid Contract, although they are in an area. While the assumption of the researcher is the arisen discourse because of the differences in a frame of the paradigm used in approaching issues and ultimately has implications for the differences in the level of understanding. Perhaps, the bigotry against the view of Muslim Scholar is rigidity, thus it makes them being unable to see Jurisprudence (in this case Jurisprudence mu'amalah) that is dynamic. ${ }^{15}$

\section{THE MEANING OF HYBRID CONTRACT}

As it is known that this article attempts to find the typology of Sasakneses Muslim scholar's views and their argumentation related to Hybrid Contract. Therefore, the theoretical framework which is used to analyze their views literally and terminologically is the meaning of the Hybrid Contract it's self. The meaning of the Hybrid Contract is similar to the al-uquid al-murakkabah in the Arabic language, where it literally is two contracts are combined to be one by putting something on the other one. The word of al-uquid al-murakeabah contains two words; al-'aquid (contracts/transaction) al-murakabah (the composed thing).The word of "al-'uqūd" (العقود) is a plural of "al-'aqd" (العقد) having the

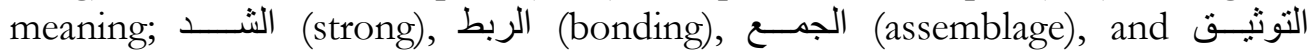
(brace) and then can be translated by meaning "some contracts". Its meaning in the Indonesian language is "Multiple Contract". In the terminology, the meaning of "Hybrid Contract" is setting some things to be one in a name, or making two contracts to be one. It means that two contracts are combined into one contract

13 See the more information at http:// nationalgeographic. co.id/berita /2016/12/indonesia-raih-12-penghargaan-bergengsi-di-ajang-the-world-halal-tourismawards-2016

14 See at http://traveling.bisnis.com/read/20160210/224/517670/lombokdestinasi-wisata-halal-terbaik-untuk-bulan-madu-

15 Akh. Minhaji, "Zakat dalam Konteks Otonomi Daerah (Perspektif Sejarah Sosial Hukum Ekonomi Islam)", dalam M. Amin Abdullah, dkk., Tafsir Baru Studi Islam di Era Multi Kultural (Yogyakarta: Kurnia Kalam Semesta, 2002), 219. 
and can not be separated from each other. ${ }^{16}$ If it is seen from the legal aspect, the Hybrid Contract is a way to do some transactions in the real life for getting the needs by agreement of both sides (buyer and seller). It refers to the text of al-Qur'an as main source of Islamic law, as in the first verses of al-maidah as follows: ${ }^{17}$

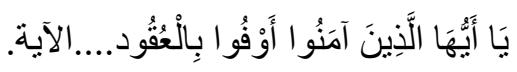

The verse above emphasizes believers that they must keep all of their contracts on any aspects, whether related to the God or humankind relation ${ }^{18}$. The contract that relates to humankind are as in buying, loan, tenancy, selling, and other contracts. They must be seriously kept, because as they are mercy from the Lord as The Creator of the creation to overcome the economic problem. The other verse supporting that people are prohibited to eat the goods of others in falsehood manner, but they are ordered to do the contract with a satisfaction of heart is as follows: ${ }^{19}$

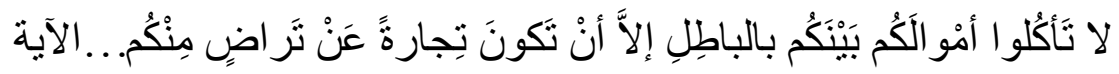

Likewise, the following verse affirms that God allows in general obtaining needs done by way of buying and purchasing, meaning that purchasing of any form is allowed as long as suitable with the rule, as in the following verse: ${ }^{20}$

$$
\text { .... وَأَحَلَّ اللهُ الْبَيْعَ وَ حَرَّمَ الرِّبَى....الآيَة. }
$$

The verse above is globally explaining that the buying and selling as kind of contract which can be established anywhere, but any kind of usury is exactly forbidden. Therefore, all of the activities related to contracts are allowed as long as it is suitable with a source; hence, Muslim scholars make the rule (qaida) considering that the contracts that have fulfilled the requirement and principle of sharia are allowed as expressed by the following qaida:

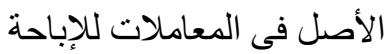

Basically, in case of action in society is allowed

16 Abdullāh bin Muḥammad bin Abdullāh al-'Imrāni, al-'Uqūd al-Māliyah alMurakkabah: Dirāsah Fiqhiyyah Ta’ṣiliyah wa Tațiquiyyah, (Riyāụ: Dār Kunūz Eshbelia li alNashr wa al-Tauz $\overrightarrow{1}, 2006)$, second printing, 45

${ }^{17}$ Qur'an verse 1 of al-Ma'idah

18 Jābir bin Mūsā bin 'Abd al-Qādir bin Abū Bakar al-Jazā’ir, Aisar al-Tafāsir li Kalām al-'Ali al-Kabìr, (al-Mamlakah al-Arabiyah al-Su'ūdiah: Makatabah al-Ulūm wa alHukum, 2003),Vol. 1, 681

${ }^{19}$ Qur'an 29 of al-Nisa'

${ }^{20}$ Qur'an 275 of al-Baqarah 
According to this rule, it can be understood that all contracts are allowed, except for the thing that is mentioned clearly as the forbidden thing, ${ }^{21}$ as it is shown by the view of Zabiriyah scholars related to the Hybrid Contract, namely it is unlawful. It is since the contracts are made without basis of law or unlawful; except, it is clearly pointed by the verses of al-Quran or Hadith about the legality of the contract. ${ }^{22}$

Therefore, the theory mentioned just now has been used by the researcher to dig the outlook of Sasaknese Muslim scholar's view that the main focus is the typology of view and the argumentation against the Hybrid Contract as the way for avoiding from the usury that becomes the social illness as pointed by "Bank Subub" and some public loan units that give the loan easily with the usury, especially in the villages where they are far from the town.

\section{THE TYPOLOGY OF TGH'S VIEW}

After analyzing comprehensively all the contents related to this study, this research showed that there are two typologies of Sasaknese Muslim scholars' views against the Hybrid Contract with their supporting argumentation; the first is Typology of Traditional Text and the second is Typology of Progressive Textual.

\section{Typology of Traditional text}

The word of traditional is taken from the word "tradition" means a belief or behavior passed down within a group or society with symbolic or special meaning from the past that exists in life. Related to this, the Sasaknese Scholars behave on traditional text, where their argumentations on Hybrid contract are built based on the belief on textual meaning from the sources of law (Al-Qur'an or Hadith). The argumentation that describes that behavior mentioned in next explanation:

a. The text of hadith

A lot of hadith of the prophet related to the Hybrid Contract can be found in the second Islamic source, namely the tradition of The Prophet, Muhammad peace be upon him. ${ }^{23}$ For example, is hadith that narrated by the Imam Baehaqi and Turmuziy in their book as seen in the next expression:

${ }^{21}$ Ibn Taimiyah, Al-Qawāiò al-Nürāniyyah al-Fiqhiyyah, (t.p: Dār Ibnu Jauziy, t.th),

22 Abū Muḥammad Ali bin Aḥmad bin Sacid bin Hazm, al-Muḥalla, j.5, (Kairo: Dār al-Turāth, tt.), 15.

${ }^{23}$ Iyadh bin Namiy al-Salma, Usyül al-Figh al-Lazi La Yas'u al-Faqiah Jahluh, (with out the publisher and year), 78 


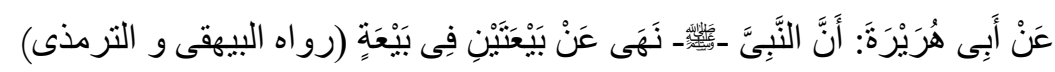
"From Abi Hurairah, that the prophet forbids two buying on the buying"24

According to the text of hadith above, explicitly, the prohibition of two buying in a buying is obvious as pointed by the word "بِيَعَنَّنِ" (two kinds of buying). This case can be exemplified by the combining of two contracts on a contract, such as the buying contract (as the one side contraction) and combined with loan contract (as the contract on another side). The combination of those contracts one transaction or as two contracts done at once in the difference time.

Regarding to the hadith text, it can be understood that the word of " "نَهَهَ"in infinitive and its meaning is "he forbids" containing the prohibition of action, such as the riba (usury), maysir (gamble), and gharar (stealth) because of all these are unfair manners to find the needs in social life, especially for the Muslim community. Hence, through the language approach, Sasaknese Muslim scholar comprehend the existence of the "Hybrid Contract" is as a forbidden thing in Islamic financial problem and this method is easier to bring someone to find the clearness of the delivered expression. Therefore, it does not need to think hard to conclude the meaning of the text and this method is suitable for the following statement:

$$
\text { لأن الظاهر إنما بدل باللفظ على ما شاع استعماله فيه؛ لأنه المتبادر إلى الذهن }
$$

"Verily, the true situation of text is shown by the expression used generally, since that is the fact which is fastest to be understood." 25

The similar example of a transaction with the combination of two contracts is ba'i al- Inab that intend for getting the profit from the transaction. It seems closer to hilah namely the action that is seen as the prohibited thing but it is explicitly allowed. ${ }^{26}$ To give the understanding against the hilah, it can be given the simple example, with the practice of ba'i al-inah, namely buying

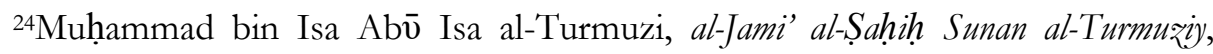
(Baerūt: Dār Iḥ̂ā’ al-Turāth al-Arabiy, tt), jilid III, 533

${ }^{25} \mathrm{Ala}$ al-Din Abi al-Husain 'Ali bin Sulaimān, al-Tahbir Syarh Fì Usyūl al-Fiqh, (Riyaḍ: Maktabah al-Rushd, 2000), 78

${ }_{26}$ Muhammad bin Shalih bin Muhammad al-Usmain, Al-syarh al-Mummta' 'Ala Zad al-Mustaqna' (ttp. Tt,) vol. 10, 65 
something with the additional payment that postponed under the aim of the owner can sell to the buyer, so he is free from debt. ${ }^{27}$

Regarding the ba'i al-Inah practice, it can commonly be shown with the practice of what someone does. For example: (A) sells bicycle in credit to his friend (B) for IDR 200.000 (two hundred thousand rupiahs). Then, (A) buys the bicycle back from (B) with a lower price, IDR 150.000 (a hundred and fifty thousand rupiahs). ${ }^{28}$ The kind of this transaction is combining two contracts, namely: the first is a combination of buying in cash by the higher price with buying which payment postponed and the lower price at the same time. It is sure; this transaction has aimed to get more profit than a usual transaction. As seen in the practice of ba'i al-Inah to fulfill the needs, here is bilah, namely avoiding transaction containing the usury.

Reviewing the hadith narrated by al-Turmuziy in his book that becomes argumentation, which further its content is analyzed with the content of practice of hybrid contract through language approach. It is understood as an attempt to comprehend a meaning from language aspect of religious text including sentence, such as the 'am (general) khäs (specific), muțlaq-muqayyad, näsikh-mansükh, 'amr (order), naby (prohibition). ${ }^{29}$ This approach is a part of manner used by the scholar of ușul al-Fiqh to understand the text of al-Qur'an and al-Hadis as explained in some literature said by, for example, Wahbah al-Zuhaili in his book, Ușūl al-Fiqh al-Islāmiy. Understood that there is in the badith the word of "نََّ" (he forbids) as the "infinitive", but its meaning is an information containing the prohibition. This sentence is known as the terminology "خبرية لفظا إنشائية معنى "30

Sasaknese Muslim scholars that include to this type of "the traditional text typology" do not admit to the Hybrid Contract as the solution to avoid usury problem as in mentioned hadith text, such as"Dana Talangan Haji product", is the product of the grant payment given by Syari'ah institution for whom will do the pilgrim worship to Mecca. The grant payment will be paid within two months after finishing the pilgrim. This product contains two

27 Wizarat al-Awqaf wa al-Shu'ūn al-Islamiyah, al-Mausū'ah al-Fiqhiyah alKunvaitiyah, (Kuait: Dār al-Salāsil, 1427 H), IX, 168

28 Abū al-Sa'ādāt al-Mubārak bin Muḥammad al-Jaziriy, al-Nihāyah fi Gharīb alAthar, (Baerūt: al-Maktabah al-Ilmiyah, 1979), volume V, 452

${ }^{29}$ Wahbah al-Zuhailiy, Ușūl al-Fiqh al-Islāmiy, (Baerut: Dār al-Fikr, 1987), jilid II, 232

30 Badar al-Din Muḥammad bin Bahard, al-Baḥr al-Muhit fi Usyül al-Fiqh, (Baerut: Dār al-Kutub al-Ilmiyah, 2000), jilid II, 456 
transactions at one time, namely loan (qard) and rent (ijaräh). ${ }^{31}$ The position of the customer who borrowed the budget is a borrower, so he does the loan, while the Syari'ah institution bank is the owner budget that rented to him. So that, here there are two contracts established at a time, namely the loan and rent. This product results in long waiting list from the previous year till next year.

The other hadith to support argumentation related to the Hybrid Contract that it is unlawful the following tradition:

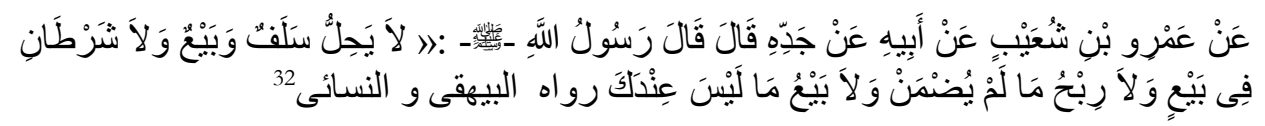

'Narrated from Amar bin Syu'aib from his father from his grandfather, that the Prophet said: "It is unlawful, that the loan and buying are combined and two conditional on the buying do not get profit (taken) before being received and you may not sell something that you do not have it”

According to the view of Sasaknese Muslim Scholar, the prohibition the Hybrid Contract is caused by the similarity of conditional contract, it is asserted in the two words; "سلف"(loan) and "وبيع (buying), namely the existence of two contracts, selling and loan as shown by hadith mentioned above.

b. Conditional Transaction

The second argumentation used by Sasaknese Muslim scholars to reject the Hybrid Contract is fiqh approach, as it is seen in their analysis in finding the hidden meaning of the badith mentioned before, where its connection to the Hybrid Contract is seen in the "Dana Talangan Haji product" and others. Surely, the hadith is addressing to activities for getting profit between a person and/or people in public area that it must be on the good track as being taught by Islamic law.

In their view, the relationship of the hadith text with the "Dana Talangan Hajı" product is pointed by the sentence " لَا يَحِلُ سَتَفْ ". Here, it can be affirmed that the analysis is "the traditional text typology" that is clear. Then, the result of Sasaknese Muslim scholars' interpretation result is similar to the interpretation of Muslim scholar against the meaning the badith

31 Muhamad Ahbar Ilyas, "Dana Talangan Haji Problem dan Relita Hukum di Kalangan Masyarakat” dalam http://blog.umy.ac.id/muhakbargowa/2012/09/26/ quoted 15 Februari 2017

32 Abū Bakar Aḥmad bin al-Husain bin Ali al-Baehaqiy, al-Sunan al-Kubra, (Hindi; Majli Dairah al-Ma'arif al-Nizamiayah, 1344H), jilid V, 267 
mentioned before as shown in the next expression taken from Subul alSalam: ${ }^{33}$

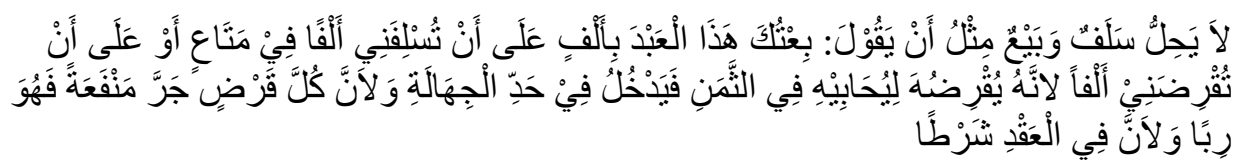

Here, the understood meaning of the text above is an example of the buying combined with the rent, where each contract has different aims, like the buying basically used to give something bought by buyer permanently to the seller. But, the aim of rent is giving the benefit to who wants to rent temporarily. So here, there is a hidden something wished by each contractor that does the contract, both as the buyer or the renter. It is known from the

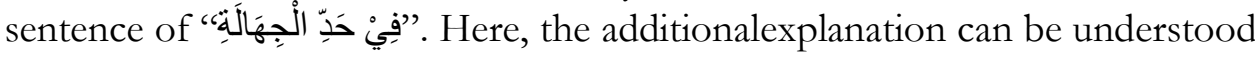
too by understanding that combination of two contracts can bring indication of the usury and conditional contract, where it is known from the sentence:

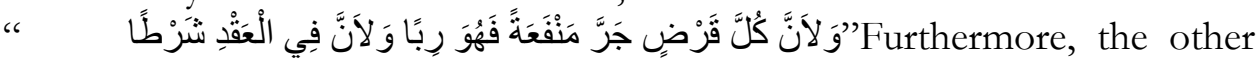
argumentation that taken from hadith is the combination of two contracts can be said as the "conditional contract" or "اشتراط عقد في عقد", namely that there is another requirement within a contract as the new contract and it must be done, so that this condition makes each contract depends on the other contract, whereas it does not have any connection. ${ }^{34}$ Of course, the requirement made by either buyer or seller is the additional bounds that are not related to the contract recognized by them before leaving each other. However, the requirement related to the contract its self as a mortgage or loan is valid, because its position is trust on the loan. ${ }^{35}$

c. Interpretation of verse

Furthermore, the other argumentation used is interception of the verses of al-Qur'an, where they forbid clearly the unlawful things, such as riba (usury), maysir (gambling), and gharar (stealth) at any transaction done by any aims and manners, because these elements are an unfair mark and that must be

33 Muḥammad bin Isma’il al-Amiry al-Kaḥlāni al-Ṣan’aniy, Subul al-Salām, (t.t.p,:Maktabah Muṣtafa al-Bābiy al-Halibiy, 1960), Jilid III, 13.

34 Shams al-Dīn 'Abi 'Abdillāh Muḥammad bin 'Abdillāh al-Zarkasi al-Mișriy alHambaliy, Sharh al-Zarkasiy 'Ala Mukhtașar al-Kharaqiy, (Baerut: Dār al-Fikr, 2002), jilid II, 93 lihat juga pada Wazā'ir al-Auqāf wa al-Shu'ūn al-Islāmiyah, al-Mausü'ah alFiqhiyah al-Kuaitiyah,.. jilid V, 290.

35 See the Majmu'ah min al-Mu'allifin, Fiqh,..., 69 
avoided. Therefore, it becomes the basic principle of the Islamic law as shown by the verse of al-Qur'an, namely: ${ }^{36}$

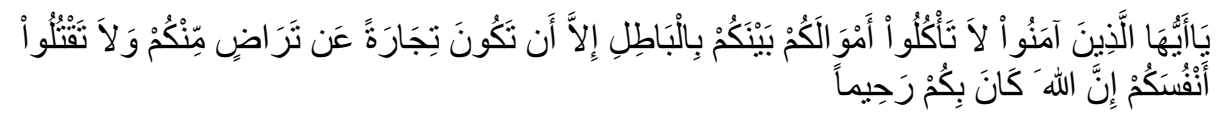

Explicitly, the verse forbids someone not to eat others' without the permission recognized well by shariah, such as buying-selling, rent, etc.thatallowedcommonly and done with the good willing from each other, both as the buyer and seller. Likewise, this verse forbids all believers not to do any kind of a forbidden thing to fulfill the needs for life, such as eating the other's goods by stealing, robbing, and etc.that are categorized as a crime in social life. The prohibition of those things are caused by the opposition with the aims of society, that are having welfare, security, calamity, happiness, and etc., that is social welfare which is dreamt by all human kinds on earth.

d. Taqlīd

To refuse the use of the Hybrid Contract as one of the ways for the transaction, Sasaknese Muslim scholar uses another approach, namely istimbath al-furu', namely taking the status of law globally from the Muslim scholar's books, where it is taken from the detail argumentation within the Islamic sources, and then it is called with term "fiqh". The meaning of fiqh is understood from the explanation of Muslim scholars separated in some recognized books and known as the furu' not usyül because this term has a different meaning and function in understanding Islamic teaching comprehensively, especially it relates to Islamic law. While the term of "fiqh" as the result of the ushül al-figh processing is explained by Muslim scholars as follows: ${ }^{37}$

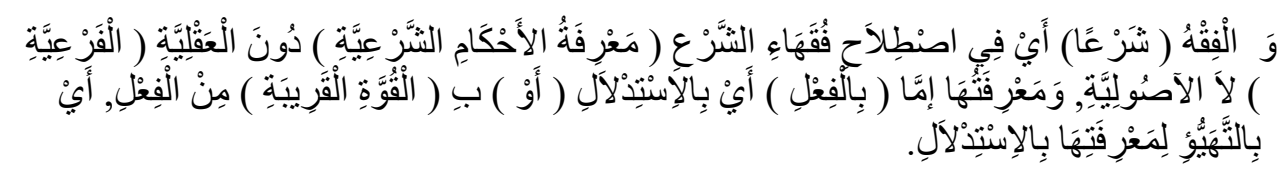

Here, they Muslim Sasaknese scholar followed the result of thinking of the Muslim scholars to determine the status of Islamic law for a case living in social life.This manner is recognized as "taqlid" in figh area, such as taqlid toward al-mazāhib al-'arba'ah. ${ }^{38}$ Here, Sasaknese Muslim scholars clearly hold

36 Al-Qur'an, al-Nis $\vec{a}$ (4) verse : 29

37 Taqiy al-Din, Sharh al-Kaukab al-Munir, (t.tp: Maktab al-Abikan, 1997), 41

38 The meaning of "taqlid" is joining the voice of the man. It is shown by Muhammad bin Husain bin Hasan al-Jizaniy, Ma'alim ushul al-Fiqh Inda 'Ahl alSunnah wa al-Jam'ah, (Makkah, Dar ibn al-Jauziy, 1427H), 36 
the madhab of Muslim scholars, especially madhab by Syafi'i. It is because that this madhab is the widest madhab in Lombok and recognized as the answer to Islamic law problem. Behind this approach, Sasaknees Muslim scholar uses the qaeda fiqhiyah too, namely the basic rule in the form of short phrases including the laws and regulations relating to some problems of law, both it is relating to worship or social action related to humankind, animal, and the other creation living on the earth as can be seen in the expression of Muslim scholars as follows: ${ }^{39}$

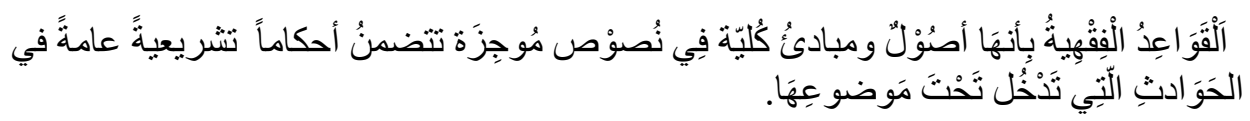

Based on the explanation concerning to the definition of qaeda fiqhiyah, it appears that Sasaknees Muslim scholars try out to do the inductive analysis (istigra $\bar{a}^{-}$) with attention all of the same factors (ashbāh) in a problem with the other problems in the figh area. So, they reject the concept of the Hybrid Contract by using the familiar qa idah fiqbiyah, that is:

كل قرض جر نفعا فهو ربا40 - كل

The meaning of this expression is that loan which takes benefits -as an additional contract- is usury, it is either a little or more benefit, because of the contract containing the forbidden aspect must be avoided and natively the contract is standing up by itself without condition. So that, this approach is used by Sasakneses Muslim scholar to explore the law of Hybrid Contract so that the conclusion is that Hybrid Contract is one of the forbidden contracts and named by " "انشتراط عقد في عقد", "namely a contract depends on another contract requirement for doing a transaction, while each requirement has not the relationship between them, such as the "loan" contract is hung on "rent" contract, while each contract has different meaning or term. The meaning of loan contract is an agreement to return what has been borrowed as defined with the next meaning follows:" تَمَلِيكُ

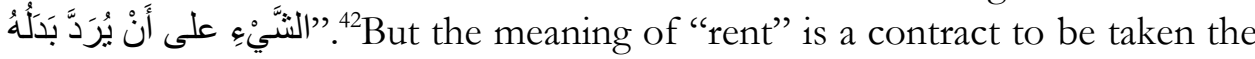

${ }^{39}$ Muḥammad al-Ḥusain, Diräsah wa Tahqüq 'Umdah al-Nazir 'Ala al-Asybäh wa alNaza'ir, (t.p.: t.t., th), 89

40 Muhammad Ashim al-Ihsan al-Mujaddiy al-Barkuniy, Qawaid al-Fiqh, (Charahi, 1986), 79

${ }^{41}$ Ibnu Hajar al-Haetami, al-Fatäwa al-Kubra, (Baerūt: Dar al-Fikr, t.th), jilid IV, 54. Lihat juga Wazāìir al-Auqāf wa al-Shu'ūn al-Islāmiyah, al-Mausū'áb al-Fiqbiyah alKuaitiyah, (Kuait: Dār al-Salāsil, 1427H), jlid V, $290 .$.

${ }^{42}$ Zakariya, Asna al-Matalib fi Sharh Raud al-Talib, (Baerut: Dar al-Kutub alIlmiyah, 2000), v 2, 140 
benefit and given the payment after using the object, it is known by definition as follows"عقد معاوضة على تمليك منفعة بعوض 43

So, the point here is the combination between the different kinds of contracts that the aims cannot be united, except if it is forced to be established without paying attention to the rule in the agreement as allowed by Islamic law, both it is coming from the contractors or the others.

\section{The Second Type is Typology of Progressive Textuality}

The various ways of thinking are the color of the growth from the human being's life and are signals making the distinction among the other creatures living on the earth, either is related to culture, politic, economic, religious, custom, laws, or the other aspects as nature. Then, the related reality, the researcher can show the other type of Sasaknese Scholars Muslim's thinking that is the Typology of Progressive Textuality. Its meaning is who has been involved in this type does not only refer to the argumentation that is not only based on the premier source; al-Qur'an and hadith, but they also progress more to recognize the concept of the Hybrid Contract to be used in the transaction between each the contractors in fulfilling the needs of life, such as the primary need, secondary need, and complementary need.Related to the topic of this study, the Hybrid Contract concept, the Sasaknese Muslim scholars develop argumentation that supports the hybrid contract in social life, either the people are as the buyer, sellers, farmer, gardener, or the other specialist profession and skill. The argument used to receive the Hybrid Contract is the following.

a. Habit Contract

According to the view of Sasaknese Muslim scholars, the Hybrid Contract is a similar contract to the others. It is recognized and has been used by the people, including the Islamic financial institution, with its Arabic name "al-uqud al-murakkabah" means combining two contracts. Broadly, it means that two contracts truly have each different impacts, and the two contracts are made to be one model to undertake the problem of Islamic finance, like in the "Dana Talangan Haji product". This product combines two transactions as the combination of al-Qard (loan) and al-Ijärah (rent), where they have a different impact. Here, it can be seen that the example uses the combination has a function to get the profit from each customer. More explanation that loan contract is one way to get a loan to pay the budget of pilgrim and also the al-ijarab contract is to find the profit for the Islamic financial institution, according to this type that service needs, where

43 Waza'ir al-Auqaf wa al-Syu'un al-Islamiyah, al-Mausu'ah al-Fiqhiyah alKuaitiyah,(Kuait: Waza'ir al-Auqaf wa al-Syu'un al-Islamiyah, with year),vol 1, 502 
all services need to pay the administration budget. That is why the combination of two contracts is not included as the parallel combination and is also not ta'alluq, namely each contract as the combination does not depend on the contract, so it is not the requirement of the transaction, but each contract is free from dependency on the other contract. For example, the alqardis a contract and al-'ijärah is a contract that does not grow because of alqardat one time since the position of al-Qard is a support to get the portion of pilgrimage. ${ }^{44}$

So, it can be affirmed here that the meaning of the combination of two contracts is that the contract, natively, does not have an impact on each other so that it does not include to meaning gharar (stealth) as forbidden by the Hadith as follows: ${ }^{45}$

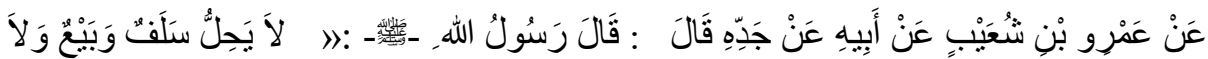

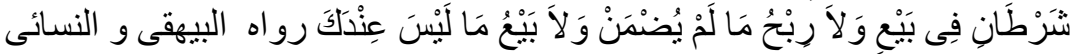

Based on the interpretation of this hadith that combination of two contracts as understood by Muslim scholars is the combination of two contracts containing gharar (stealth), obscurity contract, and so on. However, if the contract does not contain an element of deception, of course, it is allowed, as seen in the example practiced in the "Dana Talangan Haji" as a product in the Islamic Financial Institution.That is why, if it is free to contract from any kind of forbidden thing as wished by the hadith mentioned before, it is of course not allowed. Like gharar contained contract that is not a clear thing as shown in the next expression: ${ }^{46}$

الغرر هو المجهول العاقبة

Here is the researcher sees the progressive position of Sasaknese Muslim scholars against the hybrid contract, where each contract is made in a package, though basically as separated part. However, it is made as the one contract type without depending on the each other. The "Dana Talangan Haji" mentioned above contains two contracts; al-qard and al-ijarah where each transaction does not depend on the other.

b. Qaidah Fiqhiyah

It has been known that Hybrid Contract is a combination of two transactions in a transaction. Oneofthetransactions is not a requirement for

44 See the more explanation at Riduan, "Lagi Masalah Dana Talangan Haji” pada http://mridwancenter. Wordpress.com queted at 23 October 2017.

45 Abū Bakar Aḥmad bin al-Husain bin Ali al-Baehaqiy, al-Sunan al-Kubra, (Hindi; Majli Dairah al-Ma'arif al-Nizamiayah, 1344H), jilid V, 267

${ }^{46}$ Ibn Taimiyyah, Majmū al-Fatāwa, (t.t,: Dar al-Wafā', 2005).vol. XXIX, 22 
the other and it is a legal manner since it is not opposing Mu'amalah principle. All of this is based on the famous statement of Muslim scholar that all human being activities basically is allowed in Muamalah area by the Islamic rule as found in some books of figh, such as disclosed by Abdullah bin Abdurrahman bin Shalih al-Basam in his statement as shown below:

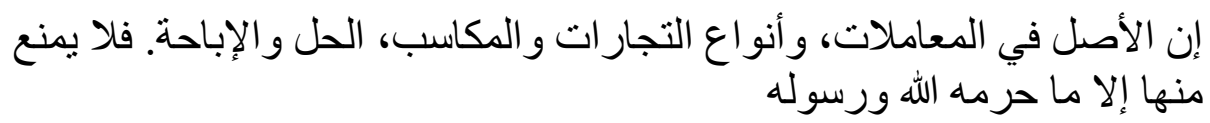

"Verily, that basic of transactions, types of trade and gains are valid and permissibility, so it is not forbidden to be done except what Allah and His Messenger have been forbidden." 47

The statement above shows that the original activity is valid except what has been recognized by The God and The Prophet as the forbidden activity. Related to the terms of Hybrid Contract issues, it seems that proponents are using the "freedom of contract analysis" based on the determination that something cannot implicitly be stated as a prohibited thing without a clear statement from the lawmakers; The God and The Prophet. Because itis based on the consideration of the philosophy value to facilitate the humankind in doing something well, and also it is the characteristic of Islamic teaching giving an easy solution for human beings to fulfill the needs, as felt by Muslim community in daily life as long as it is suitable with the norm of the religion, as expressed by the next expression bellows:

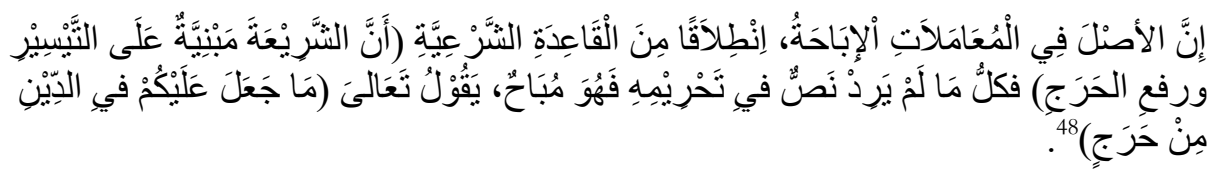

The points of the above expressions are transactions in mua'amalah field are allowed, it is based on the principle of the Islamic teaching that discards the difficulties to fulfill the needs as known in the term of "maqashidal-shari'ab".

Related to what has been studied above, Sasaknese Muslim scholars builds the argumentation supporting the validity of the "Hybrid Contract" as the solution to avoid usury in the transaction by getting back to the "basic principle of Islamic teaching" as explained by Ibn Taymiyyah in his book: alQawäid al-Nurāniyah al-Fiqhiyah, which is basically something transacted is

\footnotetext{
${ }^{47}$ Abdullah bin Abdurrahman bin Shalih al-Basam, Taisir al-Ulam Syarh Umdah al-Ahkam, (Mesir: Ain Syam, 2016), vol. 1., 449

${ }^{48}$ Ali bin Nāyif al-Shuhūd, Mausū'ah al-Buhüth wa al-Maqālāt al-Ilmiyah,(t.p.:t.t.th), 2
} 
allowed, either in a contract or two contracts, as long as there is no description of the Shari'ah blocking its validity as shown as follows: ${ }^{49}$

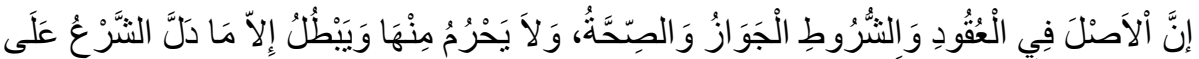

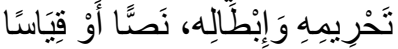

c. The changing of time

According to Sasaknese Muslim scholars that are included in "Typology of Progressive Textuality," that the "Hybrid Contract" is valid based on consideration of the changing of the time that runs fast, day after day and even year after, almost the changing can exactly not be avoided. Because it is natural when it is seen through some aspects, such as the growth of ways of thinking, the growth of the population of the country, and the exchanging of a generation living in the different periods or milieu and so on. All of these gives the wide influence to the ways of life to reach the needs of the people as wished.The changing aspects explained is one of elements to think harder to answer the problem happened in the society, especially it is related to Islamic law for Mulsim that find the difficulty in fulfilling the needs. So, "mashlahlah" is the foundation of the activity recognized in the "al-Maqāsid al-Shari"ah.

Besides the changing of the legality caused by various factors, however, another reason raised by Sasaknese Muslim scholars to admit the hybrid contract as valid and can be carried out. Though in some traditions that have been described that combination of the contract is forbidden. However, the social conditions in such a way at the moment are approaching the threshold "dharurat" (emergency). The difficult condition that must be handled becomes one reason so that the purpose of community life can be achieved by not ignoring the messages of "Shari'ah". Therefore, the Muslim scholars have made the "qaeda fiqbiyal" describing the necessity that can occupy "dharurat" (emergency) due to the changing of times, namely: alHạjjah tanæịl al-darurät.

\section{d. Maqāṣid Al-shariáh Approach}

The maquasid al-shariáh approach is the setting of law based on the intention and purpose of shariah, namely the consideration of the benefit (mashlabah), so the emphasis lies in the effort to uncover and to explain the law of a case with the benefit considerations which is applied both to cases of texts of the source; Qur'an and hadith, as well as to the cases happen without the text. The maquasid al-shar'ab is generally in line with the linguistic

${ }^{49}$ Ibnu Taemiyah, al-Qawāid Al-Nuraniyah Al-Fiqhiyah, (t.p., Dar Ibnu al-Jauziy, 1422), jilid I, 261 
approach, for example in the obligatory to prayers and fasting in Ramadhan which are understood from some verses of the Qur'an, but according to the maqāsyid approach, the obligatory is to preserve the religion aspect (hifz aldin).This maqāsid al-shar"ah approach is used by Sasaknese Muslim Scholar who support the Hybrid Contract, although it is clearly seen in some traditions used by people who reject Hybrid Contract. Otherwise, some who support hybrid contract believe some traditions support the al-Qur'an verse that forbids usury, ghrar, and maysir. Therefore, the things that implicate the ban of prophet also forbids it. Because Islam through the Qur'an wants to preserve the various joints of life (al-Nafs, al-Din, al-Mäl, al-'Aql and al-Nasl), so the hadith also supports it, because of the position of hadith as explanatory Al-Qur'an. However, when it is viewed from the general principles of the Qur'an relating to covenants, it is found that keeping the general purpose of the Qur'an is very permissible in contracts, including the Hybrid Contract are based on the original law, the original law in mu'amalah is permissible as long as there is no proposition forbid it. Therefore, making any contract is permissible under the declaration of the verse and for that reason, the 'ulama' makes qa'idabfiqhiyah:

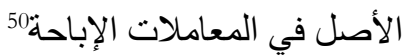

e. The Easiness of Approach (rukhșah)

In maintaining the Hybrid Contract concept, the Sasaknses's Muslim Scholars use the easiness approach to be an argumentation, so it becomes reasonable action because the contract is thought as a compulsory way to be used in current the position of the institution today, especially for LKS (Islamic Financial Institution), where it is still at an emergency position. So, the products that use hybrid contracts are carried out with the utmost consideration as possible as to avoid the prohibition of usury in a business until the public can get the right financial institution that is clean of the "assumption" or even the usage of usury the business.

Likewise, the community is in a forced situation to make a contract with a bank that considered as a conventional bank. Therefore, Sasaknese MuslimsScholar as the supporters argue that the Hybrid Contract is allowed by reason therukhșab(easiness), because it is in the "emergency" condition, even though the interpretation of the Hybrid Contract is clearly prohibited in some traditions as mentioned before. This means that the ability to use Hybrid Contract is based on emergency situation and also an emergency

50 Șālih bin Muḥammad bin Hasan al-Asmariy, Majmū'ah al-Fawàid al-Bahiyah 'Alā Manzumah al-Qawàid al-Bahiyah, (t.t.p, Dār al-Șamìiy, 2000), 75 
condition of the person is allowed to do illicit things because it was in accordance with qaidah fiqhiyah ${ }^{51}$

$$
\text { الضرورات تبيح المحظورات }
$$

The fairness to give the profit to the LKS (Sharia Financial Institutions) for example in the Syariah pawnshops or the Hajj Fund product by holding hybrid contracts supported by Sasakanese Muslim Scholar, because it is impossible that an institution can run well without any cost obtained from own business, especially in the competition condition today, where the conventional bank clearly uses the "interest" (riba). It is difficult to avoid and even it becomes an urgent thing to push a person to get the "interest". In the fiqh language, this condition is commonly called "umum albalwa", namely the condition embodying to all areas of life, such as the social culture, economy, education; even it was running to religious practice such as the pilgrim. So, someone can not escape from it and it can not be avoided. This condition was in accordance with the expression follows:

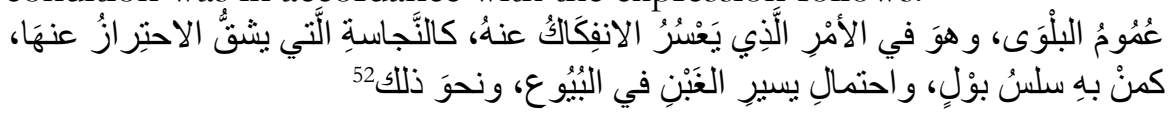

"Another definition of the emergency condition, namely the things which it was difficult to avoid a normal condition is mentioned by the expression follows"

$$
\text { هو الحالة أو الحادثة التي تشمل كثير اً من الناس ويتعذّر الاحتر از منها } 53
$$

"Conditions or events that include many people and it is difficult to be ignored"

One of the difficulty types that faced by humankind in many aspects of their life, either related to economic, political, or religion always deals with the bank who always strives for services with an interest. For example, related to religious aspect is what the Ministry of Religion orders to use the banks, such as BNI, BTN, and the other for payment of fees for students in

51 Zain al-'Abidīn bin Ibrahīm bin al-Nakhìi, al-Ashbāh wa al-Naża'ir, (Baerūt: Dār al-Kutub al-Ilmiyah, 1980), 85 lihat juga al-'Imām al-'Allāmah Tāj al-Dīn 'Abd alWahhāb bin 'Ali bin 'Abd al-Kāfì al-Subkīy, al-Ashbāh wa al-Naza'irli al-Imām Täj al-Dìn al-Subkìy, (t.p,: Dār al-Kutub al-Ilmiyah, 1991), 55 lijat 'Alā' al-Dīn 'Abī al-Hasan 'Ali bin Sulaimān al-Mardāwi al-Hambali, al-Tahrìr Sharh al-Tahrìr fì Ușūl al-Fiqh, Rìyạd: Maktabah al-Rushd, 2000), jilid VIII, 647 lihat juga 'Abū al-'Abbās 'Aḥmad bin Idrīs alȘanhāji al-Qarāfi, al-Furūq 'Auw 'Anwàr al-Burūq fì 'Anwà' al-Furūq, (Baerūt: Dār alKutub al-Ilmiyah, 1998), IV, 206

52 Zaid al-Dīn Ibn Nujaim al-Hanafi, al-Bahr al-Ra’iq Shar Kanz al-Daqa'iq, (Baerut: Dār al-Ma'rifat, t.th), 101

53 Wizarat al-Awqaf wa al-Shu'ūn al-Islamiyah, al-Mausü'ah al-Fiqhiyah alKuwaitiyah, (Kuait: Dār al-Salāsil, 1427 H), XXXI, 6 
the Islamic college. Whereas these banks take the interest as one of the advantages obtained from customers to conduct some activities with the banks. For the Hybrid Contract supporters, when they are looking for someone who can lend without interest is very difficult. Hence, the hybrid contract is allowed in order to avoid usury. Further, the convenience contracts are permissible and it is what Shariah wants to fulfill the humankind needs. Therefore scholars make the qaidah fiqbiyah, namely the expression " which it is same in the meaning with the qaidab which explains the same status with the emergency condition, namely: "الحاجة "تنزل منزلة الضرورة".

\section{CONCLUSION}

After studying the main problem mentioned above, it can be concluded that the typology of Sasaknense's Muslim Scholars is divided into two, namely the supporters and rejecters against the Hybrid Contract that is used in a contract; either it was used in an informal institution or non-formal institution. Then, each group has the argumentation based on sources and logic, although they have the same argumentation. Basically, they are different in way of thinking, where the first group goes with the text of hadith that prohibits the Hybrid Contract practice in a contact as it contains one of the prohibited things surely, namely the gambling, cheating, and usury. Therefore, the first group is known by the term Typology of Traditional Text. The second group has different argumentation. Although they get back to traditions or hadith which are used by the first group, they interpreted the text of hadith that forbids if the contract is established by mean to get usury and soon. Moreover, the changing of condition influence the needs of life. Hence, this group is called by the Typology of Progressive Textuality.

\section{REFERENCE}

'Abdillāh, Bakr, Fiqh al-Nawāril, t.t: Mu'assah al-Risālah, 1996

'Anșāriy, Zakariyā, Asna al-Maṭālib fi Sharb Raụ̣ al-Talibìn, Baerut: Dār al-Kutub al-Ilmiah, 2000.

-, Fath al-Wahhāb Sharh Minhaj al-Ṭullāb, Baerut: Dar al-Fikr, t.th.

'Asyur, Ibin, al-Tahrir wa al-Tanwìr, Tunis: Dar Sahnun, 1997.

'Iḥsān (al), Muhammad 'Amīm, Qawāid al-Fiqh, Karachi: Balsharah, 1986. 
'Imrāni (al), Abdullāh bin Muḥammad bin Abdullāh, Al-'Uqūd al-Māliyah alMurakkabah: Dirāsah Fiqhiyyah Ta’ṣiliyah wa Taṭiquiyyah, Riyaḍ: Dār Kunūz Eshbelia li al-Nashr wa al-Tauzî̀, 2006.

'Ismā'il, Abū 'Ali bin , al-Muhkeàm wa al-Muḥ̂t al-'A'zam, Bairut: Dār al-Kutub al-Ilmiyah, 2000.

'Uthaimin (al), Muḥammad bin Șālị bin Muhammad, al-Sharh al-Mumtati' 'Ala Zäd al-Mustaqna', t.p,: t.t, th.

Abdul Hayyi Nu'man dan Sahafari Asy'ari, Nabdlatul Wathan Organisasi Pendidikan, Sosial dan Politik (Lombok Timur: Pengurus Daerah NW Lombok Timur, t.th.

Abdul Munir Mulkhan (ed), Moral Politik Santri: Agama dan Pembelaan Kaum Tertindas, Jakarta: Erlangga, 2003.

Abdullah Manan, Aspek. Hukum dalam Penyelenggara Investasi di Pasar Modal Syariah Indonesia, Jakarta: Kencana Prenada Media Groupe, 2009.

Abdullah Sayed, Islamic Banking, and Intrest: Study of the prohibition of Riba and it's Contemporary InterpationLedien: Ej Brill, 1996.

'Abdurraḥmān bin Nāṣir, al-Qawāid al-Hasān fi Tafsìr al-Qur'ān, t.p.: t.t., t.th.

'Abdurrahman, Abdullah, ' Rasāil wa Fatāwa al-'Allämah 'Abdullab bin 'Abdurrabman 'Ababațin, Riyāḍ: Dār al-'Āṣimah, 1412H.

Abu Ahmadi, Filsafat Islam, Semarang: Toha Putra,1988

Abu Jaib, Sa'id, al-Qāmūs al-Fiqh Lugatan wa isyțilāha, Dimasyq: Dār al-Fikr, 1408 H/ 1988 -M.

'Abū Muqbil, Arsif Multaqa Abl al-Hadith t.p.: t.t., 2000.

'Abū Samah, Qararāt wa Taudihāt Majma' al-Fiqh al-Islämiy al-Tabi' al-Mu'tamar alIslämiy, t.t.: t.p., t.th.

'Abū Shujā', Sharh Matan al-Taqrīb fi Ghāyat al-Taqrīb, Bairut: Dār al-Fikr, t.th.

'Abu Zubaid, al-Murabahah li 'Āmir bi al-Shirā', t.p: t.t., t.th.

Adrian Sutedi, Perbankan Syariah: Tinjauan dan Beberapa Segi Hukum,Bogor: Ghalia Indonesia, 2009.

Qudāt (al), Maḥmūd, al-Hiyal al-Shar'iyah al-Ṣahīh Minha wa al-Mardūd,t.p,: t.t., t.th.

Ahmad Tafsir, Filsafat Umum, Bandung Rosdakarya, 1990.

Ahmad Taqiuddin Mansur, NU Lombok: Sejarah Terbentuknya Nabdlatul Ulama Nusa Tenggara Barat, (Lombok Barat: Pustaka Lombok, 2008. 
Ahmad Abd. Syakur, Islam dan Kebudayaan: Akulturasi Nilai-nilai Islam dalam Budaya Sasak, Yogyakarta: Penerbit Adab Press, 2006.

Ahmad, Syaikh Mahmud, Ekonomic Of Islam, Lahore: Bazar, 1968.

'Ahmad, Taqiy al-Din, Imtā' al-Asmā' bi ma li al-Nabi min al-Ahwāl wa al-Amwāl wa al-Hafadah wa al-Matā', Baerut: Dār al-Kutub al-Ilmiyah, 1999.

'Azam (al), Muḥammad Diyā' al-Rahman, al-Minnat al-Kubra Sharh wa Takhrīj alSunan al-Syugra, Riyāḍ: Maktabah al-Rusyd, 2011.

'Ābidin (al), Ibn, Hashiah Radd al-Mukhtār, Baerut: Dār al-Fikr,2000.

Askari (al), Mu'jam al-Furüq al-Lughawiyah, t.t.p, t.n.p, t.th.

Baehaqiy (al), Imam, al-Sunan al-Kubra wa Zaelibi al-Jaubar al-Naqy, (Haedar: Majlis Dā'irah al-Ma'arif al-Nizamiyah,1344H.

Bujairimiy (al), Imam, Tuhfat al-Habìb 'alā Sharh al-Khațib, Bairut: Dār al-Kutub al-Ilmiyah, 1996.

Gharwawi (al), Skhaikh, al-Sirāj al-Wahhäja 'Alā Matn al-Minhāj, Baerut: t.t., t.th. Jaram (al), Ali Wa Mustafa Amin, al-Balaghah al-Wadihah, t.p.: t.t., t.th.

Haidar, Ali, Majallah al-Aḥkām al-Adliyah, Baerut: Dār al-Jail, 1991.

Musa, Ali Maschan, "Jadilah Kiai Advokasi", dalam MajalahAula, No.02, Tahun XXVI.

Ali, Zainuddin, Hukum Gadai Syariah, Jakarta: Sinar Grafika, 2008.

Jazā'ir (al), 'Abū Bakar, Aisar al-Tafāsir li Kalam al-'Aliy al-Kabìr, Madīnah alMunawwarah: Maktab al-'Ulūm wa al-Hukum, 2003.

Khazin (al), Shaekh, Tafsìr al-Khą̄̃in al-Musamma li Bäb al-Ta'wīl Fi Ma'āniy alTanzill, Baerut: Dar al-Fikr, 1979.

Kiyaharasi (al), Shaekh Ahkām al-Qur'ān, Baerut: Dar al-Kutub al-Ilmiyah, $1405 \mathrm{H}$.

Manāwi (al), Shaekh, Faị̣ al-Qadìr, Baerūt: Dār al-Kutub al-'Ilmiyah, 1994.

Mashiqh (al), Khālid bin 'Ali, al-Mu'ämalah al-Mäliyah al-Mu'āṣirah, t.p.: t.t., t.th.

Mawardī (al), Imam, al-Ahkēm al-Sulțāniyah, Bairūt: Dār al-Fikr, tt.

----------, Imam, al-Hāwi fi Fiqh al-Shāfỉi, Dār al-Kutub al-Ilmiyah, 1994.

Nawawi (al), Shaekh al-Majmü'Sharh al-Muhazzab, Baerut: Dar al-Fikr, 1997.

Qādir (al), Khalid Muḥammad Abd Kitāb al-Ummah, t.p.: t.t.,1998.

Al-Qur'an 
Qurṭubiy (al), Ibnu Bațāl al-Bakriy, Sharh Ṣaḥ̄h al-Bukhāriy Li Ibn Baṭāl, Riyāọ: Maktabah al-Rushd, 2003.

Shaeraziy (al), Ibrahīm bin Ali bin Yūsuf, al-Mubazzab fi fiqh al-Imām al-Syäfìi, Baerut: t.t.p, t.th.

Sharahatāni, Shaekh, al-Milal wa al-Niḥal, (Libanon: Dār al-Ma'rifah, tt), jilid II, 58

Shātiby (al), Imam, Al-Muwāfaqāt, t.tp,: Dār Ibnu Affān, 1997.

Syāfi'i (al), Imam, Mukhtașar al-Muzaniy, t.p.:Bahāmis al-Umm, t.th.

Tahānawi (al), Skaekh, Kashsyāf Ishthilāhāt al-Funūn, Beirut: Dār Șādir, tt.

Zakarkasi (al), Shaekh, al-Bahr al-Muhith fi Ushül al-Fiqh, Bairut: Dar al-Kutub alIlmiyah, 2000

Anak Agung Ketut Agung, Kupu-kupu Kuning Yang Terbang di Selat Lombok (Lintasan Sejarah Kerajaan Karang Asam 1661-1950), (Bali Denpasar, PT Upadata Sastra, 1991.

Anas, Mālik Ibin, Muaț̣a’ al-Imām Mālike, Meșir: Dār Iḥyā’ al-Turāth al-‘Arabiy, t.th.

Anton Bakker dan Ahcmad Zubair, Metodologi Penelitian Filsafat, Yogyakarta: Kanisius, 1990

Antonio, Syafi'i, Bank Syariah dari Teori ke Praktek, Bandung: Pustaka Ilmu, 2000.

'Arabi, Ibnu, Abkam al-Qur'an,t.t.: t.p., t.th.

'Arabiyah (al), Hai'ah Kibar al-Ulama' bi al-Mamlakah, al-Buḥuth al-Ilmiyah, t.t,: Mauqi' al-Risālah al-'Āmmah li al-Buhūth al-Ilmiyah wa al-Iftā', t.th

'As'ad Hūmad, Aisar al-Tafāsir, t.t.p: t.t., t.th.

'Asmariy (al), Ṣālị̣ bin Muḥammad bin Hasan, Majmūah al-Fawāid al-Babiyah 'Alā Manżūmah al-Qawāid al-Babiyah, t.p.: Dār al-Șamīì, 2000.

Asmuni Mth, Aflikasi Musyarakah Dalam Perbankan Islam, al-Mawardi, Yogyakarta: Jurnal, edisi 2004.

'Athīr, Ibn, Jāmi' al-Ușūl fì Aḥādìth al-Rasūl, Dār al-Bayan, Maktabah alHulwāniy, t.th.

'Athiyah bin Muhammad Salim, Sharh Bulüg al-Maräm, (t..p.: t.t., .th.

Azharliqoh "Mengenal-fiqih-muamalat-kontemporer" dalam http://azharliqoh.

Raḥmān (al), Abdullāh bin, Rasāil wa Fatāwa al-'Allāmah Abdullāh bin Abd alRaḥmān, Riyaụ: Dār al-'Āṣimah, 1282H. 
Bachtiar, Amsal, Filsafat Agama, Jakarta: Logos,1997.

Badar (al), Muḥammad bin Bahard, al-Baḥr al-Muhit fi Usyūl al-Fiqh, Baerut: Dār al-Kutub al-Ilmiyah, 2000.

Badri (al). Abdul 'Aziz, Peran Ulama dan Penguasa (ter) Salim Muhammad Wakid (Solo: Pustaka Matiq, 1987.

Baehaqiy (al), Ahmad bin al-Husain bin 'Ali bin, al-Sunan al-Kubra wa Zailibi alJaubar al-Nuqa, Hindi: Majlis Dā’irah al-Ma’ārif al-Nizāmiyah, 1344H.

Baehaqiy (al), Ahmad bin al-Husain bin Ali, al-Arba'ūn al-Sughrā, Baerut: Dār alKitab al-Arabiy, $1408 \mathrm{H}$.

-, al-Sunan al-Kubra wa Zaelibi al-Jauhar al-Naqy, Haedar: Majlis Dā’irah alMa'ārif al-Nizamiyah,1344H.

Baghawi (al), Al-Husain bin Mas'ud, Sharh al-Hadith, Baerut: al-Maktab alIslamiy, 1983.

Bahutiy (al), Mansur bin Yūnus, al-Raud al-Murabba' Sharh Zād al-Mustaqna', t.p.: Dār al-Mu'ayyad Mu'assasah al-Risālah, t.th.

Baqā’ (al), Taqiyud al-Dīn Abū Muḥammad bin Ahmad, Sharb al-KaukabalMunir, (ttp: Maktabah al-Abikan, 1997.

Baqnah, Amir, al-Tllah Ind al-Ushuliyin, t.p: t.t.,t.th.

Brayan S. Tuner, Social Theory, Balack Well Publishing, 2009.

Bruggink, J.J.H. Refleksi Tentang Hukum. Alih Bahasa oleh B. Arief Sidharta, Bandung: Citra Aditya Bakti, 1996.

Budiwanti, Erni, Islam Sasak: Wetu Telu Versus 'Waktu Lima ,Yogyakarta: LKiS, 2000

Bujaerimiy (al), Sulaimān bin Umar bin Muhammad, Hashiyah al-Bujaerimiy 'Ala Sharh Minhaj al-Tullāb, Turkiya: Diya Bakar, t.th.

Bukhariy (al), Muhammad, al-Hiyal fi al-Shari'ah al-Islämiyah, Kaero: Maṭba'ah alSa'ādah, 1974.

, al-Mughirah, al-Jami' al-Musnad al-Shabih al-Mukhtasyar,(t.p.: Dar Thuq al-Najah, 1422. 